\title{
Freely Dissolved Organochlorine Pesticides (OCPs) and Polychlorinated Biphenyls (PCBs) along the Indus River Pakistan: Spatial pattern, Air-water Exchange and Risk Assessment
}

\section{Muhammad Sohail}

COMSATS University Islamabad

Syed Ali Musstjab Akber Shah Eqani

COMSATS University Islamabad

Habib Bokhari

COMSATS University Islamabad

Muhammad Zaffar Hashmi ( $\square$ hashmi_qau@yahoo.com )

COMSATS Institute of Information Technology, Islamabad, Pakistan

Nadeem Ali

King Abdulaziz University

Ambreen Alamdar

COMSATS University Islamabad

Joel E Podgorski

Swiss Federal Institute of Aquatic Science and Technology

Dave Adelman

University of Rhode Island

Rainer Lohmann

University of Rhode Island

\section{Research Article}

Keywords: OCPs, PCBs, passive sampling, Indus River.

Posted Date: June 15th, 2021

DOI: https://doi.org/10.21203/rs.3.rs-554439/v1

License: (1) This work is licensed under a Creative Commons Attribution 4.0 International License.

Read Full License 


\section{Abstract}

Freely dissolved OCPs and PCBs were measured by using polyethylene passive samplers, at 15 sites during 2014 throughout the stretch of Indus River to investigate spatial pattern, air-water exchange gradients and risk assessment. Concentrations (pg/L) of dissolved $\sum$ OCPs and $\sum$ PCBs ranged from 341600 and 3-230. Among the detected OCPs, dissolved DDTs (p,p'-DDE, followed by p,p'-DDT) predominated with levels of 0.48 to $220 \mathrm{pg} / \mathrm{L}$. The order of occurrence for other studied OCPs was as follows; HCB, Endosulfans, Chlordanes, and HCHs. Spatially, dissolved $(\mathrm{pg} / \mathrm{L}) \sum \mathrm{OCPs}$ varied $(p<0.05)$ as: surface water of Alluvial Riverine Zone (ARZ) showed highest levels (114) followed by Frozen Mountain Zone (FMZ) (52.9), Low Lying Zone (LLZ) (28.73) and Wet Mountain Zone (WMZ) (14.43) respectively. However, our zone wise PCBs data did not exhibit significant differences $(p>0.05)$. The PCA/MLR results showed that pesticides usage in crop/orchard fields and health sector, electric \& electronic materials, and widespread industrial activities as the main source of OCPs and PCBs along Indus River. Air-water exchange of OCPs at FMZ, o,p'-DDE, p,p'-DDE and o,p'-DDD exhibited net volatilization while $p, p^{\prime}-D D D / o, p^{\prime}-D D T$ showed net deposition, while all other studied zones (i.e., WMZ, ARZ and LLZ) showed net deposition of DDTs. Nevertheless, air-water exchange of PCBs showed that, there was net volatilization at the FMZ, WMZ and ARZ and net deposition at LLZ. Our results showed that OCPs and PCBs contaminated water intake, played an important role towards the considerable cancer/non-cancer risk (HI and CR values) along the Indus River Flood-Plain.

\section{Capsule}

The study highlighted the LRAT of POPs into northern colder areas Pakistan and highlighted the reemission of POPs into Indus River System

\section{Introduction}

Persistent organic pollutants (POPs) including organochlorine pesticides (OCPs) are widely used as pesticides for the crop protection and in health sector for malarial control (Ahad et al. 2010, Ali et al. 2014, Eqani et al. 2012b). Whereas industrial applications of polychlorinated biphenyls (PCBs) are enlisted in paints and cements as plasticizers, in polyvinyl chloride (PVC) coatings as stabilizing additives, reactive flame retardants, pesticide extenders and sealants for the caulking, adhesives and coolants in electronic/electric industry (Sweetman \&Jones 2000, Zhao et al. 2017). Due to wide scale of POPs usage, these chemicals are expected to be emitted into the surrounding environment including water bodies (e.g. lakes, rivers, marine ecosystem etc.) via surface runoff, and causing severe health impacts into aquatic/marine organisms and associated wildlife (Abbasi et al. 2015, Eqani et al. 2012b, Khan et al. 2017, Malik et al. 2011)Nawab et al., 2020). Given that OCPs and PCBs have low water/octanol $\left(\mathrm{K}_{\mathrm{ow}}\right)$ values and great affinity/potential to magnify into the food chain due to their lipophilic characteristics and resulted into accumulate in many aquatic organisms (i.e., fish) and cause variety of adverse health impacts to the exposed aquatic organism (Eqani et al. 2013, Gulland 1995, Sanpera et al. 2003). Additionally, some aquatic organisms contributed major part of the human diet and 
pass on the accumulated toxic contaminants to human beings via dietary intake. Many studies reported that POPs-contaminated fish poses several health risks to the exposed human populations in various parts of the world (Dougherty et al. 2000, Eqani et al. 2013, Kalyoncu et al. 2009, Olsson et al. 2000). Human beings are exposed to POPs via several routes, which include the contaminated air inhalation, dust ingestion/inhalation, water and food (especially fish) (Ali et al. 2013, Dirtu \&Covaci 2010, Eqani et al. 2012b, Maes et al. 2008, Whitehead et al. 2015). Exposure to POPs may also cause severe human health impacts, which includes endocrine disruption, reproductive disorder, carcinogenic, neurological and immunological problems and birth defects (Bertazzi et al. 1998, Johnson-Restrepo et al. 2005, Kortenkamp 2008, Lee et al. 2010, Taylor et al. 2013).

OCPs and PCBs are also well known semi-volatile organic compounds (SVOCs), which have the potential to volatilize and re-emit from secondary sources (from previously contaminated environments), undergo long-term and short-term atmospheric transport (in semi-arid/arid areas), and ultimately deposited into remote colder and/or high altitudinal locations, in particular north, south and third pole environment (Nasir et al. 2014, Wania \&Haugen 1999). The process of transport of such SVOCs to long distances mainly occurs due to temperature and altitudinal variation and is well known as "Long Range Atmospheric Transport (LRAT)" and confirmed by many studies (Cincinelli \&Dickhut 2011, Daly \&Wania 2005, Davidson et al. 2003). Moreover, studies have also confirmed that remote colder areas acts as repositories of these chemicals, and in context of climate change, these repositories become highly active for remobilizing the chemicals in air and to the freshwater resources, which resulted in a major threat to human and wild life being through bio-accumulation processes (Khairy \&Lohmann 2012, 2013, Sacks \&Lohmann 2011)

Many studies have described the use of novel passive samplings i.e., Low density polyethylene (LPDEs) for detecting/measuring POPs in various compartments of environment for exposure monitoring and to POPs risk evaluating on human and wild-life at regional and global scales. Passive sampling gained considerable attention for their continuous sampling of contaminant from environment and also catching episodic exposure in water (Schäfer et al. 2008, Shaw \&Mueller 2009). However, studies along the Indus river Pakistan are still scarce, and no study has done so for on passive sampling of water to measure the dissolved POPs fraction in the surface water. Similarly, the authenticated data from Pakistan on dissolved fraction of POPs is also needed as previously studies followed questionable method of water sampling and/or they collected the water samples including the suspended particulate material, which overestimate the concentrations of "dissolved" POPs. The problem can be overcome by following few recent studies from USA and European labs, which have described the use of these novel passive samplings (i.e., LPDEs and PS, PUFs) for detecting/measuring POPs in different water bodies (Harner et al. 2006, Levy et al. 2009, Lohmann \&Muir 2010). Additionally, open burning of e-waste has also been reported to release a huge amount of PCBs and other flame retardants (Novel brominated flame retardants (NBFRs) and organophosphorus flame retardants (OPFRs) (Gioia et al. 2011, Tang et al. 2010, Wong et al. 2007). It is well known that E-waste such as electronic waste consists of heterogeneous mixture containing flame retardants (FRs), polychlorinated biphenyls (PCBs), and various other hazardous compounds (Robinson, 2009). However, (lqbal et al. 2015, lqbal et al. 2017) has pointed out 
that there is lack of the reliable data, different inventories and research studies addressing e-waste issues in Pakistan and which is one of the major source of PCBs in different areas of country.

The present study was conducted for reporting the levels, distribution and apportionment of emission sources of POPs (i.e., organochlorine pesticides (OCPs), polychlorinated biphenyls (PCBs) into the Indus River, Pakistan. The study has aimed on the following main objectives. 1) To investigate the levels, compositional pattern, potential sources, and risk assessment of POPs into the Indus water ecosystem of Pakistan via passive sampling. 2) To study the air-water exchange and cycling of POPs into ambient air and surface water of Indus River.

\section{Materials And Methods}

\section{Study Area and Field Strategies}

The Indus flood-plain area is inhibited by more than 100 million human people and these areas is dependent on Indus River for agricultural activities and for fishing. The Indus River originates in the Tibetan plateau near the Lake Mansarovar, take a course via the Ladakh region (Jammu and Kashmir), Gilgit Baltistan and then flows towards south direction along entire length of Pakistan and then merges into Arabian Sea near Karachi, Sindh Pakistan. Indus River is the largest as well as longest river that flows throughout the entire length from north to south of Pakistan and its catchment area possesses diverse ecological systems i.e., snow capped northern areas, lower Himalyian mountainous valleys, agricultural plains in the south and coastal areas near Arabian sea. The Indus River also runs through the densely polluted and populated industrial cities of Punjab Province and the Khyber Pakhtunkhwa (KPK) Province, Pakistan, receiving a greater amount of pollutants from the industrial and municipal effluents through various streams and its tributaries such as Chenab River, Ravi River and Jhelum River.

After the preliminary survey of study area, fifteen sampling sites were selected along the entire stretch of Indus River, where the passive samples were installed during 2014. These sites include Gilgit, Hunza, Skurdu, Swat (Gullibagh, Kalam, Malamjaba), Swabi, Nowshera Mianwali, Bakkar, Layyah, D.G Khan, Khairpur and Hyderabad. The detailed description of each site is given as Text S1 and Table. S1. Sites location was identified in the catchment using a GPS (Global Positioning System, Garmin) and mobile weather station was used for recording the climatic data of each studied site. Low Density Polyethylene sheets (LDPE) were deployed in the surface waters for three weeks. LDPE passive water samplers were deployed $1 \mathrm{~m}$ below the surface attached to small buoys. Each sampler was assembled at the deployment sites for avoiding contamination in transportation. At the completion of the deployment period, the LPDE were retrieved, resealed and returned to Lohmann Lab, University of Rhode Island, and stored frozen until further analysis.

\section{Passive sampling for water}


First, a roll of about $2 \mathrm{~cm}$ wide, $60 \mathrm{~cm}$ long and 100 microns thick polyethylene (PE) tubing was cut off and cleaned with hexane. They were treated twice for $24 \mathrm{~h}$ in graduated cylinder with $250 \mathrm{~mL} n$-hexane and were cleaned from inside and dried in a nitrogen stream for 30 minutes. Subsequently, these tubes were welded (front and back twice) and put for storage in container. For the spiking, two performance reference compounds (PRCs) such as TCmX and PCB-29 were selected which are deuterated possible structural isomers of the substances. For this step, a polyethylene tube was put in $1.5 \mathrm{~L}$ bottle containing $1 \mathrm{~L}$ of water and then added $10 \mu \mathrm{g}$ of deuterated substance.

These were first capped and clamped for 72 hours in over headed shaker ( $15 \mathrm{rpm}$ speed). Discarded the solution and the tubes dried with the pulp and frozen till outdoor exposure. For the deployment, the polyethylene tubes were then placed in space provided by the grating and screwed. The grill was attached with the steel hook in water and give exposure for up to three weeks. A photo was taken for documentation, quality assurance (Fig. S4). The field blanks were carried for capturing the background contamination. The grills were removed after three weeks. The detailed methods have been reported elsewhere (Schäfer et al. 2010).

\section{Extraction and Clean-up of passive water samples}

Details of LDPE extraction can be found elsewhere (Khairy \&Lohmann 2013). Briefly, the PE tubes were cold extracted twice in ethyl acetate each for 24 hours after spiking with $10 \mu \mathrm{L}$ of surrogate standards PCB-209 and TCmX for calculating method recovery. The resulting extracts were combined and concentrated to $1 \mathrm{~mL}$ on a turbovap, solvent exchanged to the hexane, and concentrated to $~ 50 \mu \mathrm{L}$ using a gentle stream of ultrapure nitrogen. Injection standard was added for volume correction to all sample extracts prior to analysis.

\section{Chromatographic Analysis}

Persistent organic pollutants (POPs) such as DDTs (o,p'-DDD, p,p'-DDD, o,p'-DDE, p,p'-DDE, o,p'-DDT, p,p'$\mathrm{DDT}), \mathrm{HCB}, \mathrm{HCHs}(\mathrm{a}-\mathrm{HCH}, \beta-\mathrm{HCH}, \delta-\mathrm{HCH}$ and $\gamma-\mathrm{HCH})$, cis-chlordane (CC), trans-chlordane (TC) and trans nonachlordane (non-trans), Endosalfan I, Endosalfan II, Endosalfan salphate, Adlrin, Endrin, Methoxychlor, Heptachlore and Polychlorinated Biphenyl ( $\sum_{31}$ PCBs) PCB-11, PCB-28, PCB-58, PCB-74, PCB-70, PCB-44, PCB-49, PCB-37, PCB-60, PCB-66, PCB-77, PCB-82, PCB-87, PCB-101, PCB-123, PCB-118, PCB-114, PCB126, PCB-105, PCB-153, PCB-187, PCB-169, PCB-156, PCB-128, PCB-166, PCB-158, PCB-183, PCB-198, PCB-195, PCB-189 and PCB-170) were analyzed by GC-El-MS applied with 50m capillary column (Varian, CP-Sil $8 \mathrm{CB}, 50 \mathrm{~m}, 0.25 \mathrm{~mm}, 0.25 \mu \mathrm{m})$. The injector temperatures were set to $250^{\circ} \mathrm{C}$. The initial temperature of oven were set at $150^{\circ} \mathrm{C}$ for $3 \mathrm{~min}$, and then raised to $290^{\circ} \mathrm{C}$ at a rate of $4^{\circ} \mathrm{C} / \mathrm{min}$ and held for 10 min. Persistent organic pollutants (POPs) were then determined in selected ion mode (SIM). MSD sources and quadrupole temprature were $230^{\circ} \mathrm{C}$ and $150^{\circ} \mathrm{C}$. The MS used in this case were in SIM mode having two ions monitored for each of the target compound group in a specific window. DDT inlet degradation was daily checked and control within the $15 \%$. All the persistent organic pollutants (POPs) were quantified using HP-Chemstation to confirm the peaks. 


\section{Statistical Analysis}

Analytical results were organized to form a multielemental database by using Excel software. Graphical representation of POPs data was made using Microsoft Excel 2016 and Arc-GIS (version 10.2) was used for showing various sampling locations on map and the spatial distribution of different chemicals. A level of $p<0.05$ was considered statistically significant for multiple comparisons. A one-way ANOVA then followed by Tukey's HSD post hoc test were employed for making multiple comparisons among the different contaminants and zones. Principal component analysis/Multilinear Regression (PCA/MLR) by using SPSS Statistics (version 21) was then performed for investigating the qualitative source for target OCPs and PCBs measured in the water of Indus River, Pakistan. The detail of calculations of Air-water exchange gradient of OCPs and PCBs, water sampling rate, and human health risk assessment is describes as Text S-2, S-3 and S-4 in the supplementary material.

\section{Quality assurance \& Quality control (QA/QC)}

All the samples were first subjected to have strict quality control measure. For QA/QC, all the instruments were daily calibrated with the calibration standards. Solvent blanks, the field blanks and the procedural blanks were analyzed by using the same procedure as for the real samples. For every batch, internal standards were then injected into Gas Chromatogram before the sample injection. Moreover, surrogate standards (PCB-209 and TCmX) were also added to all the samples (LPDE) before installation in the field for monitoring matrix effects and procedural performance. Mean surrogate recoveries calculated for the PCB-209 and TCmX, ranging between $70-105 \%$ and $60-75 \%$ for PCB-209 and TCmX. Reported concentration of OCPs and PCBs were corrected to surrogate recoveries. DiBB (2,5 dibromobiphenyl), TeBB (2,2'5,5' tetrabromobiphe), PeBB (2,2',4,5',6 pentabromobi) and OCN added before GC-MS analysis as an internal standard. The processing of data acquisition was controlled by Agilent MSD Productivity Chemstation software. All the chemicals were of analytical grade and were purchased from the Merck, Germany. All solvents used in this study, redistilled for purifying solvents to reduce any interference effects of solvents. All glassware used in this study were baked $\left(450^{\circ} \mathrm{C}\right)$ for 6 hours prior to use.

\section{Results And Discussion}

\section{Freely dissolved OCPs and PCBs}

Sampling rates (Rs) for water passive samplers are given in (Table S2). The value of sampling rate for polyethylene passive water samplers were ranging from 7.4 to $91 \mathrm{~L}$ /day at all sampling sites. These values of sampling rate are consistent with the sampling rate of study done from water at wetland mountain sites of S-SE Brazil (Meire et al. 2016). Rs value for Hyderabad site (S-15) of low-lying zones (LLZ) showed highest values (91 L/day) while Gilgit site (S-2) of frozen mountain zones (FMZ) showed low sampling rate i.e., $1.0 \mathrm{~L} /$ day. 
Freely dissolved OCPs levels ranged from $34-1600 \mathrm{pg} / \mathrm{L}$ throughout Indus River as shown in Table 1 \& Fig. 1. Among the studied OCPs, DDTs (0.48-220) were dominated, followed by endosulfan (0.20-14), HCBs (0.23-6.4), chlordane (0.09-4.58) and HCH (BDL-2.64). p,p'-DDE accounted for higher frequency among the studied OCPs at most of studied site locations. In contrast, trans nonachlor $(0.09 \mathrm{pg} / \mathrm{L})$ was among the less frequently detected pesticide into the surface water of the Indus River. The freely dissolved levels of OCPs in various zones showed the trends as follows; Alluvial Riverine zone (ARZ) ranged from (19.28-259.7 pg/L) > Frozen mountain zone $(\mathrm{FMZ})(2.77-201.8 \mathrm{pg} / \mathrm{L})>$ Low lying zone (LLZ) (1.67-58.05 pg/L) and > Wet mountain zone (WMZ) (1.35-42.24 pg/L) in descending order, respectively. The concentrations OCPs measured at WMZ and FMZ are in accordance with those of reported in water of Glacial-fed lakes, Ice melting-fed lake and Rain-fed lake in remote alpine lakes located in Himalayas, Pakistan (Nawab et al. 2020) and valley of Kashmir (Ullah et al., 2019). The current OCPs values are much lower than those detected from the previously studied surface water samples from River Chenab (Eqani et al. 2012b), and River Ravi, Pakistan (Baqar et al. 2018). The previously reported high levels from Pakistan may be due to use of outdated sampling/analytical techniques, which resulted into overestimated values of studied OCPs and PCBs. In previous studies conducted at Pakistan, the authors (Baqar et al. 2018, Eqani et al. 2012b) documented the active water sampling followed by the liquid-liquid extraction method, which reflected both dissolved and suspended particulate material associated POPs level. 
Table 1

Freely dissolved OCPs (pg/L) from the four different studied zones along the Indus River, Pakistan.

\section{Freely Dissolved OCPS}

$(\mathrm{pg} / \mathrm{L})$

HCBs

$\mathrm{Y}-\mathrm{HCH}$

Transchlordane

(2)

Cischlordane

Cischlordane

Std

$\begin{array}{ll}\text { Mean } \pm & 0.40 \pm \\ \text { Std } & 0.64\end{array}$

$\begin{array}{ll}\text { Mean } \pm & 2.89 \pm \\ \text { Std } & 2.06\end{array}$

Min-Max

$<\mathrm{BDL}-$
1.42

Transnonachlor

Mean \pm
Std

$0.18 \pm$
0.29

Min-Max 0-0.69

Dieldrin

a

a-Endosulfane

a

Endosulfane

Sulfate

Sulfate

Studied Zone

Overall 


\begin{tabular}{|c|c|c|c|c|c|c|}
\hline \multirow{2}{*}{$\begin{array}{l}\text { Freely Dissolved } \\
\text { OCPs } \\
\text { (pg/L) }\end{array}$} & & \multicolumn{4}{|c|}{ Studied Zone } & \multirow[t]{2}{*}{ Overall } \\
\hline & & FMZ & WMZ & ARZ & LLZ & \\
\hline \multirow[t]{2}{*}{ PP-DDE } & $\begin{array}{l}\text { Mean } \pm \\
\text { Std }\end{array}$ & $\begin{array}{l}29.31 \pm \\
60.82\end{array}$ & $\begin{array}{l}3.35 \pm \\
4.74\end{array}$ & $\begin{array}{l}50.14 \pm \\
67.44\end{array}$ & $\begin{array}{l}17.67 \pm \\
24.63\end{array}$ & $\begin{array}{l}29.89 \pm \\
52.71\end{array}$ \\
\hline & Min-Max & $\begin{array}{l}0.36- \\
152.96\end{array}$ & $\begin{array}{l}<\mathrm{BDL}- \\
6.70\end{array}$ & $\begin{array}{l}8.18- \\
150.38\end{array}$ & $\begin{array}{l}0.26- \\
37.09\end{array}$ & $\begin{array}{l}<\mathrm{BDL}- \\
152.96\end{array}$ \\
\hline \multirow[t]{2}{*}{ OP-DDD } & $\begin{array}{l}\text { Mean } \pm \\
\text { Std }\end{array}$ & $\begin{array}{l}1.74 \pm \\
2.30\end{array}$ & $\begin{array}{l}0.45 \pm \\
0.63\end{array}$ & $\begin{array}{l}3.52 \pm \\
3.83\end{array}$ & $\begin{array}{l}0.61 \pm \\
0.77\end{array}$ & $1.90 \pm 2.63$ \\
\hline & Min-Max & $\begin{array}{l}<\mathrm{BDL}- \\
5.96\end{array}$ & $\begin{array}{l}<\mathrm{BDL}- \\
0.90\end{array}$ & $0.27-8.88$ & $0.06-1.15$ & $\begin{array}{l}<\mathrm{BDL}- \\
8.88\end{array}$ \\
\hline \multirow[t]{2}{*}{ PP-DDD/OP-DDT } & $\begin{array}{l}\text { Mean } \pm \\
\text { Std }\end{array}$ & $\begin{array}{l}4.24 \pm \\
5.04\end{array}$ & $\begin{array}{l}0.65 \pm \\
0.55\end{array}$ & $\begin{array}{l}6.51 \pm \\
7.79\end{array}$ & $\begin{array}{l}1.58 \pm \\
2.19\end{array}$ & $4.00 \pm 5.33$ \\
\hline & Min-Max & $\begin{array}{l}0.16- \\
12.75\end{array}$ & $0.27-1.04$ & $\begin{array}{l}0.63- \\
17.43\end{array}$ & $0.04-3.13$ & $0.04-17.43$ \\
\hline \multirow[t]{2}{*}{ PP-DDT } & $\begin{array}{l}\text { Mean } \pm \\
\text { Std }\end{array}$ & $\begin{array}{l}11.50 \pm \\
13.46\end{array}$ & $\begin{array}{l}1.84 \pm \\
2.00\end{array}$ & $\begin{array}{l}12.30 \pm \\
15.96\end{array}$ & $\begin{array}{l}5.31 \pm \\
7.34\end{array}$ & $\begin{array}{l}9.47 \pm \\
12.20\end{array}$ \\
\hline & Min-Max & $\begin{array}{l}0.29- \\
34.75\end{array}$ & $0.42-3.25$ & $\begin{array}{l}1.46 \pm \\
35.34\end{array}$ & $\begin{array}{l}0.12- \\
10.51\end{array}$ & $0.12-35.34$ \\
\hline \multirow[t]{2}{*}{ DDTs } & $\begin{array}{l}\text { Mean } \pm \\
\text { Std }\end{array}$ & $\begin{array}{l}48.14 \pm \\
75.24\end{array}$ & $\begin{array}{l}6.58 \pm \\
8.33\end{array}$ & $\begin{array}{l}77.13 \pm \\
99.73\end{array}$ & $\begin{array}{l}26.31 \pm \\
36.53\end{array}$ & $\begin{array}{l}47.37 \pm \\
71.95\end{array}$ \\
\hline & Min-Max & $\begin{array}{l}0.81- \\
197.89\end{array}$ & $\begin{array}{l}0.69- \\
12.47\end{array}$ & $\begin{array}{l}11.82- \\
224.24\end{array}$ & $\begin{array}{l}0.48- \\
52.14\end{array}$ & $\begin{array}{l}0.48- \\
224.24\end{array}$ \\
\hline
\end{tabular}

Historically, DDTs has been reported to be widely used OCPs for controlling the crop pests and malarial outbreaks in Pakistan (Eqani et al. 2012a, Malik et al. 2011). Along the Indus River, DDT and its metabolites (p,p'-DDE) were frequently detected as shown in Fig. 2a. The freely dissolved concentration of DDTs ranged from $0.48-224.2 \mathrm{pg} / \mathrm{L}$. Moreover, the dissolved $\mathrm{p}, \mathrm{p}^{\prime}-\mathrm{DDE}$ concentration ranged from 0.36-152.9 pg/L ( mean: 29) and consistent with already reported values of p,p'-DDE in Lake Erie (19 $\mathrm{pg} / \mathrm{L}$ ) (Blanchard et al. 2008). Other DDTs followed the occurrence order in descending order as; $p, p^{\prime}-D D T$ (0.12-35.34; mean: 9.47), p,p'-DDD/o,p'-DDT (0.04-17.43; 4.2), o,p'-DDE (0.6-12.21; 2.11) and o,p'-DDD $(0.06-8.88 ; 1.90)$. Our DDTs levels are relatively higher than those of wetland mountain region of S-SE Brazil (0.2-0.3 pg/L) (Meire et al. 2016). (Schreiber et al. 2013) reported the analogous DDTs levels to current study, as dissolved p,p'-DDEs fraction in the upland surface water of the River Xanaes in the Central Argentina was measured as $70-340 \mathrm{pg} / \mathrm{L}$. Nevertheless, various ratios between parent compound and their metabolites are reported into the literature, to track/fingerprint the possible sources, their age and usage patterns at specific areas/region (Jiang et al. 2009). It has been documented that dechlorination of DDTs may convert their isomers to its metabolites e.g., p, p'-DDT into p, p'-DDE in the presence of aerobic condition and reductively converted into the $p, p^{\prime}-D D D$ in the presence of anaerobic conditions (Zhang et al. 2006). Hence, DDT/(DDD + DDE) $<1$, showed the historical usage of DDTs 
whereas value greater than unity indicated fresh/current usage (Gao et al. 2013, Jiang et al. 2009). In present study, p,p'-DDT / $\left.p, p^{\prime}-D D E+p, p^{\prime}-D D D\right)$ value is lower than unity at most of the studied location with few exceptions included the sites of Swat, Hunza and Gilgit of FMZ, where DDTs diagnostic ratios indicating the current as well historical usage of this banned pesticide. Additionally, the values for the DDD/DDE ranging from 0.09-5.95 (with mean value of 0.65). Generally, all the sites showed the values below unity and reflected the aerobically degradation of DDTs in these areas, might be due to the frequent ploughing/crop cultivation in the agricultural field. In contrary, Hunza site showed the DDD/DDE as 5.95 and indicating that the DDT in the soil is metabolized in anaerobic environment, which can be explained by high organic matter contents and its microbial degradation in these forests covered areas. The o,p'DDT/p,p'-DDT ratio has reported to assess the usage of dicofol as possible additional source of DDTs in the environment. The ratio of the o,p'-DDT / p,p'-DDT ranged from 0.2 to 0.3 in the technical DDT and is $7.0 \pm 2.2$ in dicofol (Qiu et al. 2005). In the current study, ratio of the o,p'-DDT / p,p'-DDT ranged from 0.23 to 0.98 and highlighted that the major usage of technical DDT in the Indus flood plain (Fig. S2).

Among the $\mathrm{HCHs}, \mathrm{Y}-\mathrm{HCH}$ contributed significantly among all dissolved $\mathrm{HCH}$ and ranged between $0.20-$ $2.34 \mathrm{pg} / \mathrm{L}$. These trends for $\mathrm{HCHs}$ occurrence into the surface water of Indus water can be justified due to higher water solubility of $\mathrm{y}-\mathrm{HCH}$. Moreover, lindane (containing $90 \%$ of $\mathrm{Y}-\mathrm{HCH}$ ) has also been reported to be used in current study areas (Eqani et al. 2012a, Eqani et al. 2012b) which resulted to find its way into the aquatic ecosystem through surface runoff. In contrary to this, other $\mathrm{HCHs}(\beta-\mathrm{HCH}$ and $\mathrm{a}-\mathrm{HCH})$ have more affinity ( $\mathrm{K}_{\mathrm{ow}} \sim 3.8$ and 3.72) to bind/adsorb onto the surface of suspended particulate material and finally deposited into the bed sediments (Eqani et al. 2011). The value of HCHs were consistent with those values observed into the Great Lake (4 pg/L) (Khairy et al. 2014). The current values are lower than those detected from the surface water of River Chenab (Eqani et al. 2012b), and River Ravi, Pakistan (Baqar et al. 2018) and Chinese fresh water resources (Luo et al. 2004, Tang et al. 2008) and from Kolleru Lake, India (Sreenivasa Rao \&Ramamohana Rao 2000). Nevertheless, freely dissolved chlordanes (trans-, cis-, and trans-nonachlor isomers) detected at many instances ( $>50 \%$ of total samples) along the Indus River. Concentrations of trans-chlordane were slightly higher than cis-chlordane and the ratio of TC/CC >1 were taken generally to be indicative of recent usage of chlordanes. Trans-nonachlor (TN)/TC ratio in technical chlordane is reported as 0.42 and the ratio TN/TC is 0.52 in Indus River indicating the lower concentration of trans-nonachlor as compared to trans-clordane. The concentration of freely dissolved total chlordane $(0.96 \mathrm{pg} / \mathrm{L})$ into the Indus River is lower than those compared with the lake Erie $(56 \mathrm{pg} / \mathrm{L})$ (Khairy et al. 2014). In Pakistan, wide scale application of endosulfan have been reported for the crop protection, which cause variety of health abnormalities (Eqani et al. 2012a, Islam et al. 2018). In our study, $\sum$ endosulphans ranged from $B D L-12.83 \mathrm{pg} / \mathrm{L}$ as dissolved fraction throughout the Indus river. Among the various zones, WMZ $(6.41 \mathrm{pg} / \mathrm{L})$ showed higher concentration of dissolved endosulfan followed by ARZ $(2.89 \mathrm{pg} / \mathrm{L})>\mathrm{FMZ}(0.91 \mathrm{pg} / \mathrm{L})>\mathrm{LLZ}(0.90 \mathrm{pg} / \mathrm{L})$. In general, endosulphans compositional trends showed the dominance of endosulfan-I and endosulfan sulphates and reflected the current as well as aged use of this insecticide (Weber et al. 2010). However, our measured levels are much lower than those found in Pakistani water bodies (Ahad et al. 2006, Baqar et al. 2018, Eqani et al. 2012b) and in mountain water and snowpack sample of the Western USA National Park (44-1500 pg/L) (Blais et 
al. 1998, Blais et al. 2001). Similarly, HCB were also detected at most of the sampling sites throughout the studied stretch of the Indus River, Pakistan and its concentrations ( $\mathrm{pg} / \mathrm{L}$ ) ranged as 0.23 to 6.41 . The mean values of HCBs in various studied zones followed the trends as; ARZ (3.11 pg/L) followed by > FMZ $(2.89 \mathrm{pg} / \mathrm{L})>\operatorname{WMZ}(0.50 \mathrm{pg} / \mathrm{L})>\mathrm{LLZ}(0.45 \mathrm{pg} / \mathrm{L})$ in descending order. These HCB concentrations are consistent with the HCB concentration in the South Atlantic (1.9-3.3 pg/L), and South Pacific (0.4-0.8 $\mathrm{pg} / \mathrm{L}$ ) open water transects (Zhang \&Lohmann 2010). However, these HCB values are relatively lower than those reported from River Chenab, Pakistan $(0.29-87 \mathrm{ng} / \mathrm{L}$ and $0.43-87 \mathrm{ng} / \mathrm{L}$ during summer and winter seasons, respectively) (Eqani et al. 2012b). These concentration are also lower from the Baiertang waters, China and Yellow river, China (Luo et al. 2004, Tang et al. 2008) and from Kolleru Lake, India (Sreenivasa Rao \&Ramamohana Rao 2000). Moreover, these HCBs concentration were also much lower as compared to the concentrations reported in the South American freshwater bodies i.e. 1000-10,000 $\mathrm{ng} / \mathrm{L}$ (UNEP, 2002).

In Indus River water, total freely dissolved concentration (pg/L) of $\sum_{21}$ PCBs measured at frozen mountain zone (FMZ) as 7.44-226 (average value: 95.36) followed by at wet mountain zone (WMZ) as 41.91-199 pg/L (120.54), at alluvial riverine zone (ARZ) 30.88-144.96 (82.02) and at low lying zone (LLZ) as 3.02-26.69 (14.86). The descriptive statistic of total concentration of freely dissolved $\sum_{21}$ PCBs are given in Table 2. The occurrence trends of different PCBs homologues into Indus River follows the order as: tri-CBs $(\sim 29-71 \%)>$ penta-CB $(\sim 3-9 \%)>$ tetra-CB $(\sim 3-8 \%)>$ octa-CBs $(\sim 3-6 \%)>$ hexa-CBs $(\sim$ $2-3 \%)>$ hepta-CBs $(\sim 1-2 \%)$ (Fig. 2b). The present study has shown that levels of PCBs at FMZ, WMZ and ARZ were consistent with the levels reported for Lake Erie (52-330 pg/L) and Lake Ontario 110-190 pg/L (Anderson et al. 1999, Khairy \&Lohmann 2013) and high-mid altitude remote areas of Himalayas, Pakistan (Nawab et al. 2020). The concentration of $\sum_{21}$ PCBs (7.44-226) were relatively lower than those reported for River Chenab, Pakistan (Eqani et al., 2018), Minjiang Estuary, China (203.9-2473 ng/L) (Zhang et al. 2003), Tonghui River, China (31.58-344.9 ng/L) (Zhang et al. 2004) and Daya Bay, China (91.1-1355.3 ng/L) (Zhou et al. 2001). The current compositional profiles into Indus River complement the commercial PCBs formulation of arochlor-1242 -1260, -1262 and 1248 (Fig. S3). The $\sum_{7}$ dioxin like PCBs levels ranged from $0.07-0.81 \mathrm{pg} / \mathrm{L}$ (median: $0.35 \mathrm{pg} / \mathrm{L}$ ) with higher value found into the urban areas of ARZ (nearby D.G Khan site) due to extensive urbanization and industrial activities in this region. Fingerprinting of these contaminants has suggested to be very important because of their tetrachlorodibenzo -p-dioxins (TCDDs) like carcinogenic properties (Eqani et al. 2012b, Zhao et al. 2006). $\mathrm{WHO}_{05}$-TEQs of the mono-ortho dioxins like PCBs $(-105,-114,-118$, and - 156) and non-ortho dioxin like PCBs (-77, - 126, -169) were calculated which ranged from 0.000009-0.000043 (median: 0.000012) and $0.000009-0.00032$ (median: 0.00015) pg TEQ L ${ }^{-1}$ into all samples (Table S5). Among the individual mono-ortho DL-PCBs and the non-ortho DL- PCBs, PCB-105 and - 169 contributed very significantly toward total calculated TEQs. Higher TEQs for mono-ortho DL-PCBs were calculated at ARZ followed by LLZ, FMZ and WMZ which showed the higher industrial activity at ARZ. 
Table 2

Freely dissolved PCBs (pg/L) from the four different studied zones along the Indus River, Pakistan.

\begin{tabular}{|c|c|c|c|c|c|c|}
\hline \multirow{2}{*}{$\begin{array}{l}\text { Freely dissolved } \\
\text { PCBs }\end{array}$} & & \multicolumn{4}{|c|}{ Studied Zones } & \multirow[t]{2}{*}{ Overall } \\
\hline & & FMZ & WMZ & ARZ & LLZ & \\
\hline \multirow[t]{2}{*}{ PCB-8 } & $\begin{array}{l}\text { Mean } \pm \\
\text { Std }\end{array}$ & $\begin{array}{l}1.85 \pm \\
2.03\end{array}$ & $0.84 \pm 0.92$ & $\begin{array}{l}2.27 \pm \\
3.20\end{array}$ & $\begin{array}{l}0.36 \pm \\
0.08\end{array}$ & $1.61 \pm 2.12$ \\
\hline & Min-Max & $\begin{array}{l}0.14- \\
5.16\end{array}$ & $0.20-1.49$ & $0.49-7.06$ & $0.30-0.41$ & $0.14-7.06$ \\
\hline \multirow[t]{2}{*}{ PCB-11 } & $\begin{array}{l}\text { Mean } \pm \\
\text { Std }\end{array}$ & $\begin{array}{l}3.76 \pm \\
4.00\end{array}$ & $5.08 \pm 6.27$ & $\begin{array}{l}8.97 \pm \\
9.61\end{array}$ & $\begin{array}{l}1.41 \pm \\
0.80\end{array}$ & $5.10 \pm 6.17$ \\
\hline & Min-Max & $\begin{array}{l}0.29- \\
9.42\end{array}$ & $0.65-9.51$ & $\begin{array}{l}1.04 \pm \\
22.86\end{array}$ & $0.84-1.98$ & $\begin{array}{l}0.29- \\
22.86\end{array}$ \\
\hline \multirow[t]{2}{*}{ PCB-18 } & $\begin{array}{l}\text { Mean } \pm \\
\text { Std }\end{array}$ & $\begin{array}{l}1.69 \pm \\
1.90\end{array}$ & $0.89 \pm 1.05$ & $\begin{array}{l}1.11 \pm \\
1.09\end{array}$ & $\begin{array}{l}0.24 \pm \\
0.10\end{array}$ & $1.20 \pm 1.42$ \\
\hline & Min-Max & $\begin{array}{l}0.23- \\
4.76\end{array}$ & $0.14-1.63$ & $0.48-2.75$ & $0.17-0.31$ & $0.14-4.76$ \\
\hline \multirow[t]{2}{*}{ PCB-28 } & $\begin{array}{l}\text { Mean } \pm \\
\text { Std }\end{array}$ & $\begin{array}{l}2.48 \pm \\
2.00\end{array}$ & $1.79 \pm 2.53$ & $\begin{array}{l}4.81 \pm \\
4.73\end{array}$ & $\begin{array}{l}1.37 \pm \\
1.28\end{array}$ & $2.89 \pm 3.01$ \\
\hline & Min-Max & $\begin{array}{l}0.48- \\
4.84\end{array}$ & $0.00-3.58$ & $\begin{array}{l}1.37- \\
11.71\end{array}$ & $0.46-2.28$ & $0.00-11.71$ \\
\hline \multirow[t]{2}{*}{ PCB-44 } & $\begin{array}{l}\text { Mean } \pm \\
\text { Std }\end{array}$ & $\begin{array}{l}0.07 \pm \\
0.14\end{array}$ & $0.03 \pm 0.04$ & $\begin{array}{l}0.07 \pm \\
0.14\end{array}$ & $\begin{array}{l}0.01 \pm \\
0.01\end{array}$ & $0.06 \pm 0.11$ \\
\hline & Min-Max & $\begin{array}{l}<\mathrm{BDL}- \\
0.35\end{array}$ & $\begin{array}{l}<\mathrm{BDL}- \\
0.06\end{array}$ & $\begin{array}{l}<\mathrm{BDL}- \\
0.29\end{array}$ & $\begin{array}{l}<\mathrm{BDL}- \\
0.02\end{array}$ & $\begin{array}{l}<\mathrm{BDL}- \\
0.35\end{array}$ \\
\hline \multirow[t]{2}{*}{ PCB-66 } & $\begin{array}{l}\text { Mean } \pm \\
\text { Std }\end{array}$ & $0.7 \pm 0.61$ & $0.39 \pm 0.55$ & $\begin{array}{l}1.83 \pm \\
1.04\end{array}$ & $\begin{array}{l}1.38 \pm \\
1.69\end{array}$ & $1.07 \pm 0.98$ \\
\hline & Min-Max & $\begin{array}{l}0.25- \\
1.88\end{array}$ & $\begin{array}{l}<\mathrm{BDL}- \\
0.78\end{array}$ & $0.90-3.26$ & $0.18-2.57$ & $\begin{array}{l}<\mathrm{BDL}- \\
3.26\end{array}$ \\
\hline \multirow[t]{2}{*}{ PCB-101 } & $\begin{array}{l}\text { Mean } \pm \\
\text { Std }\end{array}$ & $\begin{array}{l}0.72 \pm \\
0.51\end{array}$ & $1.19 \pm 0.06$ & $\begin{array}{l}1.57 \pm \\
0.84\end{array}$ & $\begin{array}{l}0.09 \pm \\
0.13\end{array}$ & $0.94 \pm 0.73$ \\
\hline & Min-Max & $\begin{array}{l}<\mathrm{BDL}- \\
1.47\end{array}$ & $1.14-1.23$ & $0.49-2.49$ & $0.00-0.18$ & $0.00-2.49$ \\
\hline \multirow[t]{2}{*}{ PCB-123 } & $\begin{array}{l}\text { Mean } \pm \\
\text { Std }\end{array}$ & $<\mathrm{BDL}$ & $<\mathrm{BDL}$ & $\begin{array}{l}0.07 \pm \\
0.13\end{array}$ & $\begin{array}{l}0.09 \pm \\
0.12\end{array}$ & $0.03 \pm 0.08$ \\
\hline & Min-Max & $<\mathrm{BDL}$ & $<\mathrm{BDL}$ & $0.00-0.26$ & $0.00-0.18$ & $0.00-0.26$ \\
\hline PCB-118 & $\begin{array}{l}\text { Mean } \pm \\
\text { Std }\end{array}$ & $\begin{array}{l}0.22 \pm \\
0.15\end{array}$ & $<\mathrm{BDL}$ & $\begin{array}{l}0.46 \pm \\
0.19\end{array}$ & $\begin{array}{l}0.43 \pm \\
0.54\end{array}$ & $0.29 \pm 0.26$ \\
\hline
\end{tabular}




\begin{tabular}{|c|c|c|c|c|c|c|}
\hline \multirow{2}{*}{$\begin{array}{l}\text { Freely dissolved } \\
\text { PCBs }\end{array}$} & & \multicolumn{4}{|c|}{ Studied Zones } & \multirow[t]{2}{*}{ Overall } \\
\hline & & FMZ & WMZ & ARZ & LLZ & \\
\hline & Min-Max & $\begin{array}{l}<\mathrm{BDL}- \\
0.43\end{array}$ & $<\mathrm{BDL}$ & $0.24-0.71$ & $\begin{array}{l}0.04 \pm \\
0.81\end{array}$ & $\begin{array}{l}<\mathrm{BDL}- \\
0.81\end{array}$ \\
\hline \multirow[t]{2}{*}{ PCB-105 } & $\begin{array}{l}\text { Mean } \pm \\
\text { Std }\end{array}$ & $\begin{array}{l}0.08 \pm \\
0.10\end{array}$ & $0.08 \pm 0.11$ & $\begin{array}{l}0.08 \pm \\
0.10\end{array}$ & $\begin{array}{l}0.02 \pm \\
0.02\end{array}$ & $0.07 \pm 0.09$ \\
\hline & Min-Max & $\begin{array}{l}<\mathrm{BDL}- \\
0.23\end{array}$ & $\begin{array}{l}<\mathrm{BDL}- \\
0.16\end{array}$ & $\begin{array}{l}<\mathrm{BDL}- \\
0.21\end{array}$ & $\begin{array}{l}<\mathrm{BDL}- \\
0.03\end{array}$ & $\begin{array}{l}<\mathrm{BDL}- \\
0.23\end{array}$ \\
\hline \multirow[t]{2}{*}{ PCB-126 } & $\begin{array}{l}\text { Mean } \pm \\
\text { Std }\end{array}$ & $\begin{array}{l}0.01 \pm \\
0.02\end{array}$ & $<B D L$ & $<B D L$ & $<\mathrm{BDL}$ & $\begin{array}{l}<\mathrm{BDL} \pm \\
0.01\end{array}$ \\
\hline & Min-Max & $\begin{array}{l}<\mathrm{BDL}- \\
0.06\end{array}$ & $<\mathrm{BDL}$ & $<\mathrm{BDL}$ & $<\mathrm{BDL}$ & $\begin{array}{l}<\mathrm{BDL}- \\
0.06\end{array}$ \\
\hline \multirow[t]{2}{*}{ PCB-153 } & $\begin{array}{l}\text { Mean } \pm \\
\text { Std }\end{array}$ & $\begin{array}{l}0.22 \pm \\
0.29\end{array}$ & $0.20 \pm 0.28$ & $\begin{array}{l}0.11 \pm \\
0.22\end{array}$ & $\begin{array}{l}0.03 \pm \\
0.05\end{array}$ & $0.16 \pm 0.23$ \\
\hline & Min-Max & $\begin{array}{l}<\mathrm{BDL}- \\
0.63\end{array}$ & $\begin{array}{l}<\mathrm{BDL}- \\
0.40\end{array}$ & $\begin{array}{l}<\mathrm{BDL}- \\
0.44\end{array}$ & $\begin{array}{l}<\mathrm{BDL}- \\
0.06\end{array}$ & $\begin{array}{l}<B D L- \\
0.63\end{array}$ \\
\hline \multirow[t]{2}{*}{ PCB-138 } & $\begin{array}{l}\text { Mean } \pm \\
\text { Std }\end{array}$ & $\begin{array}{l}0.21 \pm \\
0.13\end{array}$ & $0.22 \pm 0.31$ & $\begin{array}{l}0.44 \pm \\
0.27\end{array}$ & $\begin{array}{l}0.32 \pm \\
0.45\end{array}$ & $0.29 \pm 0.24$ \\
\hline & Min-Max & $\begin{array}{l}0.04- \\
0.41\end{array}$ & $\begin{array}{l}<\mathrm{BDL}- \\
0.43\end{array}$ & $0.14-0.77$ & $\begin{array}{l}<\mathrm{BDL}- \\
0.64\end{array}$ & $\begin{array}{l}<\mathrm{BDL}- \\
0.77\end{array}$ \\
\hline \multirow[t]{2}{*}{ PCB-128 } & $\begin{array}{l}\text { Mean } \pm \\
\text { Std }\end{array}$ & $\begin{array}{l}0.02 \pm \\
0.05\end{array}$ & $<\mathrm{BDL}$ & $<B D L$ & $<\mathrm{BDL}$ & $0.01 \pm 0.03$ \\
\hline & Min-Max & $\begin{array}{l}<\mathrm{BDL}- \\
0.12\end{array}$ & $<B D L$ & $<\mathrm{BDL}$ & $<B D L$ & $\begin{array}{l}<\mathrm{BDL}- \\
0.12\end{array}$ \\
\hline \multirow[t]{2}{*}{ PCB-156 } & $\begin{array}{l}\text { Mean } \pm \\
\text { Std }\end{array}$ & $<\mathrm{BDL}$ & $<\mathrm{BDL}$ & $\begin{array}{l}0.05 \pm \\
0.15\end{array}$ & $<\mathrm{BDL}$ & $0.02 \pm 0.08$ \\
\hline & Min-Max & $<\mathrm{BDL}$ & $<\mathrm{BDL}$ & $\begin{array}{l}<\mathrm{BDL}- \\
0.30\end{array}$ & $<\mathrm{BDL}$ & $\begin{array}{l}<\mathrm{BDL}- \\
0.30\end{array}$ \\
\hline \multirow[t]{2}{*}{ PCB-169 } & $\begin{array}{l}\text { Mean } \pm \\
\text { Std }\end{array}$ & $<\mathrm{BDL}$ & $<\mathrm{BDL}$ & $\begin{array}{l}<\mathrm{BDL}- \\
0.01\end{array}$ & $<\mathrm{BDL}$ & $<\mathrm{BDL}$ \\
\hline & Min-Max & $<B D L$ & $<B D L$ & $\begin{array}{l}<\mathrm{BDL}- \\
0.01\end{array}$ & $<\mathrm{BDL}$ & $\begin{array}{l}<\mathrm{BDL}- \\
0.01\end{array}$ \\
\hline \multirow[t]{2}{*}{ PCB-187 } & $\begin{array}{l}\text { Mean } \pm \\
\text { Std }\end{array}$ & $\begin{array}{l}0.58 \pm \\
1.34\end{array}$ & $0.16 \pm 0.23$ & $\begin{array}{l}0.06 \pm \\
0.08\end{array}$ & $\begin{array}{l}0.06 \pm \\
0.09\end{array}$ & $0.30 \pm 0.87$ \\
\hline & Min-Max & $\begin{array}{l}<\mathrm{BDL}- \\
3.31\end{array}$ & $\begin{array}{l}<\mathrm{BDL}- \\
0.32\end{array}$ & $0.00-0.16$ & $\begin{array}{l}<\mathrm{BDL}- \\
0.13\end{array}$ & $\begin{array}{l}<\mathrm{BDL}- \\
3.31\end{array}$ \\
\hline PCB-180 & $\begin{array}{l}\text { Mean } \pm \\
\text { Std }\end{array}$ & $\begin{array}{l}0.06 \pm \\
0.06\end{array}$ & $0.14 \pm 0.19$ & $\begin{array}{l}0.24 \pm \\
0.19\end{array}$ & $\begin{array}{l}0.10 \pm \\
0.06\end{array}$ & $0.13 \pm 0.14$ \\
\hline
\end{tabular}




\begin{tabular}{|c|c|c|c|c|c|c|}
\hline \multirow{2}{*}{$\begin{array}{l}\text { Freely dissolved } \\
\text { PCBs }\end{array}$} & & \multicolumn{4}{|c|}{ Studied Zones } & \multirow[t]{2}{*}{ Overall } \\
\hline & & FMZ & WMZ & ARZ & LLZ & \\
\hline & Min-Max & $\begin{array}{l}<\mathrm{BDL}- \\
0.14\end{array}$ & $\begin{array}{l}<\mathrm{BDL}- \\
0.27\end{array}$ & $\begin{array}{l}<\mathrm{BDL}- \\
0.42\end{array}$ & $0.06-0.14$ & $\begin{array}{l}<\mathrm{BDL}- \\
0.42\end{array}$ \\
\hline \multirow[t]{2}{*}{ PCB-170 } & $\begin{array}{l}\text { Mean } \pm \\
\text { Std }\end{array}$ & $\begin{array}{l}0.04 \pm \\
0.09\end{array}$ & $<B D L$ & $\begin{array}{l}0.02 \pm \\
0.03\end{array}$ & $\begin{array}{l}0.04 \pm \\
0.06\end{array}$ & $0.03 \pm 0.06$ \\
\hline & Min-Max & $\begin{array}{l}<\mathrm{BDL}- \\
0.21\end{array}$ & $<\mathrm{BDL}$ & $\begin{array}{l}<\mathrm{BDL}- \\
0.06\end{array}$ & $\begin{array}{l}<\mathrm{BDL}- \\
0.09\end{array}$ & $\begin{array}{l}<\mathrm{BDL}- \\
0.21\end{array}$ \\
\hline \multirow[t]{2}{*}{ PCB-195 } & $\begin{array}{l}\text { Mean } \pm \\
\text { Std }\end{array}$ & $\begin{array}{l}1.07 \pm \\
2.29\end{array}$ & $1.24 \pm 1.75$ & $\begin{array}{l}1.22 \pm \\
1.12\end{array}$ & $\begin{array}{l}0.01 \pm \\
0.01\end{array}$ & $0.98 \pm 1.65$ \\
\hline & Min-Max & $\begin{array}{l}<\mathrm{BDL}- \\
5.70\end{array}$ & $\begin{array}{l}<\mathrm{BDL}- \\
2.48\end{array}$ & $\begin{array}{l}<\mathrm{BDL}- \\
2.64\end{array}$ & $\begin{array}{l}<B D L- \\
0.01\end{array}$ & $\begin{array}{l}<\mathrm{BDL}- \\
5.70\end{array}$ \\
\hline \multirow[t]{2}{*}{ PCB-206 } & $\begin{array}{l}\text { Mean } \pm \\
\text { Std }\end{array}$ & $\begin{array}{l}81.6 \pm \\
91.72\end{array}$ & $\begin{array}{l}108.30 \pm \\
97.02\end{array}$ & $\begin{array}{l}58.63 \pm \\
38.50\end{array}$ & $\begin{array}{l}8.92 \pm \\
11,66\end{array}$ & $\begin{array}{l}68.47 \pm \\
72.19\end{array}$ \\
\hline & Min-Max & $\begin{array}{l}3.54- \\
219.15\end{array}$ & $\begin{array}{l}39.70- \\
176.91\end{array}$ & $\begin{array}{l}20.53- \\
93.01\end{array}$ & $\begin{array}{l}0.67- \\
17.16\end{array}$ & $\begin{array}{l}0.67- \\
219.15\end{array}$ \\
\hline \multirow[t]{2}{*}{$\sum \mathrm{PCBs}$} & $\begin{array}{l}\text { Mean } \pm \\
\text { Std }\end{array}$ & $\begin{array}{l}95.36 \pm \\
92.7\end{array}$ & $\begin{array}{l}120.54 \pm \\
111.2\end{array}$ & $\begin{array}{l}82.02 \pm \\
51.90\end{array}$ & $\begin{array}{l}14.86 \pm \\
16.73\end{array}$ & $\begin{array}{l}83.65 \pm \\
76.83\end{array}$ \\
\hline & Min-Max & $\begin{array}{l}7.44- \\
226.40\end{array}$ & $\begin{array}{l}41.91- \\
199.17\end{array}$ & $\begin{array}{l}30.88- \\
144.96\end{array}$ & $\begin{array}{l}3.02- \\
26.69\end{array}$ & $\begin{array}{l}3.02- \\
226.40\end{array}$ \\
\hline
\end{tabular}

Table 3

Chemical daily intake (CDI pg/person/day) of OCPs and PCBs through Oral and dermal exposure from surface water of Indus River.

\begin{tabular}{|lllllllll|}
\hline $\begin{array}{l}\text { Studied } \\
\text { POPs }\end{array}$ & FMZ & \multicolumn{3}{c}{ WMZ } & \multicolumn{3}{c|}{ ARZ } & \multicolumn{3}{c|}{ LLZ } \\
\cline { 2 - 9 } & $\begin{array}{l}\text { CDI } \\
\text { oral }\end{array}$ & $\begin{array}{l}\text { CDI } \\
\text { dermal }\end{array}$ & $\begin{array}{l}\text { CDI } \\
\text { oral }\end{array}$ & $\begin{array}{l}\text { CDI } \\
\text { dermal }\end{array}$ & $\begin{array}{l}\text { CDI } \\
\text { oral }\end{array}$ & $\begin{array}{l}\text { CDI } \\
\text { dermal }\end{array}$ & $\begin{array}{l}\text { CDI } \\
\text { oral }\end{array}$ & $\begin{array}{l}\text { CDI } \\
\text { dermal }\end{array}$ \\
\hline p,p'-DDD & 8.26 & 0.02 & 1.26 & 0.003 & 12.65 & 0.03 & 3.07 & 0.007 \\
\hline p,p'-DDE & 56.99 & 0.13 & 6.51 & 0.01 & 97.49 & 0.23 & 34.35 & 0.08 \\
\hline p,p'-DDT & 22.36 & 0.05 & 3.57 & 0.008 & 23.91 & 5.82 & 10.32 & 0.02 \\
\hline $\begin{array}{l}\text { Y- } \\
\text { HCH/lindane }\end{array}$ & & & & & 1.28 & 0.003 & & \\
\hline$\Sigma C h l o r d a n e$ & 1.49 & 0.003 & 0.99 & 0.0024 & 3.15 & 0.0076 & 1.18 & 0.0045 \\
\hline$\Sigma P C B s$ & 185.42 & 0.45 & 233.33 & 0.57 & 159.48 & 0.38 & 28.89 & 0.07 \\
\hline
\end{tabular}


Principal component analysis/multiple linear regression (PCA/MLR) describes and identifies between the related and the unrelated source tracer and also percentage contribution from the various sites along the Indus River, Pakistan. PCR/MLR was performed on the data of OCPs and PCBs for individual metabolites of DDTs, $\mathrm{HCH}$ s and PCBs homologues (i.e., tri-CB, tetra-CB, penta-CB, hexa-CB, hepta-CB and octa-CB) using varimax rotation method (Fig. S7).

In frozen mountain zone (FMZ), the PCA extracted four components (explaining 33.33, 26.18, 23.80 and 13.02 variability, respectively) and also shown as Table S8. The PC-1 accounted for $33.33 \%$ variance and highlighted the p, $p^{\prime}-D D D, o, p^{\prime}-D D T, o, p^{\prime}-D D E$, and p,p'-DDE. In the past, DDTs were used for agricultural purposes and malarial control program and PCA-MLR has also indicated the historical as well as current illegally use of DDTs in agriculture and health sector in the studied area. Diagnostic ratios for DDTs in these areas has also indicated its fresh and/or aged uses of DDTs in these areas. Moreover, wet and dry deposition of atmospheric dust particles through the process of altitudinal fractionation can also justify the DDTs contamination in these areas (Khan et al. 2017, Sohail et al. 2018). Atmospheric DDT fallout into the freshwater ecosystem has also been reported worldwide as $>150 \mathrm{Kg} \Sigma \mathrm{DDT}$ dust borne contamination has been estimated to the Great Lakes, USA and which was due to wet and dry deposition (Hoff et al. 1996). The PC-1 also dominated by various polychlorinated biphenyles including octa-CB, hepta-CB and penta-CB, which reflected the long range dust borne $\mathrm{PCBs}$ contamination into this area (Eqani et al. 2012b). The PC-2 was accounted for $26.18 \%$ of the total variance and dominated by HCBs, hexa-CB and tri-CB. HCB act as intermediate product used in preparation of the OCPs and other industrial activities (Tolosa et al. 2010, Zhao et al. 2010). In the studies area, HCB might find their way into surface water via run off from contaminated soils and/or via dry and wet deposition of long range atmospheric particulate material. The PC-2 has also highlighted the hexa-CB and tri-CB and indicated the dry and wet deposition of long range atmospheric particulate material from surrounding countries (China and India and low-lying areas of Pakistan) into these high altitudinal areas as source of these pollutants. The presence of lower molecular weight PCBs can be linked through the gaseous deposition of these contamination via cold trapping process (Ali et al. 2017). The PC-3 accounted for $23.80 \%$ of the total variance and dominated by octa and penta-CB, which are industrial chemicals used for paints, plastics, electronic goods such as capacitors and transformer oil and can present into these areas due to long term dust particles deposition from nearby regions. The PC- 4 was accounted for $13.02 \%$ of the total variance and dominated by $p, p^{\prime}-\mathrm{DDT}$ and indicated fresh usage of DDTs in these areas.

PCA/MLR results for the wet mountain zone (WMZ) showed that only one factor explained $>90 \%$ of the variation in data and highlighted the DDTs metabolites, HCBs and all CBs, originating from the common source. As mentioned earlier that lower Himalayans areas are historically receiving POPs/metals contaminated dust from Indus floodplain and low-lying areas, which build up POPs/metals levels in these areas and now in context of rapid urbanization these contaminants are continually emitting into the environment (Alamdar et al. 2016, Eqani et al. 2016). Moreover, rapid urbanization in these mountainous areas is also associated to various environmental problems and wide range of chemicals are being used in these areas for industrial purposes and emit PCBs and HCBs from painted surfaces, electrical appliances, plastics, PVC materials etc. (Khan et al. 2017, Sohail et al. 2018). DDTs emission in these 
areas may also be the consequence of urbanization and emitted via dry/wet depositional from nearby areas, where the usage of these chemicals are suspected for different purposes including malarial control, protection of timber and indoor environments (Ali et al. 2014, Nasir et al. 2014, Sohail et al. 2018). Moreover, historical usage of DDTs and presence of obsolete pesticide store and abandoned DDT factories in these areas may also contributed towards the high levels of its metabolites (DDD, DDE) and find its way into Indus river via surface run off (Sohail et al., 2018).

For the alluvial riverine zone (ARZ), two extracted components (PC-1 and PC-2) accounted $93 \%$ of the total variance in the POPs data from the Indus River. PC-1 factor accounted $54.18 \%$ of the total variance and was dominated by p,p'-DDE, followed by o,p'-DDE, p,p'-DDT, p,p'-DDD/o,p'-DDT, and o,p'-DDD and highlighted the current and/or aged usage of DDTs in these well-known agricultural areas. Moreover, hepta-CBs highlighted by PC1 and points the industrial activities in these areas, which resulted into contamination of Indus river via various local drains and posed several ecological risks to Indus river ecosystem. The PC-2 has accounted $39.28 \%$ of the total variance and highlighted tri-CB, tetra-CB, penta$\mathrm{CB}$, octa-C and $\mathrm{HCBs}$ and reflected the industrial activities in these areas as major sources of these chemicals.

For the low-lying zone (LLZ), we considered PC-1 which explained more than $90 \%$ of the variance in data obtained from the Indus River and highlighted a mixed source containing of pesticides and electronics. Agricultural application of pesticides as well as industrial activities are the main reasons for the contamination of this zone. All districts included in LLZ zones are characterized by harsh climatic conditions (i.e. wind storms, high temperature, less vegetation cover and low rainfall) and historical agricultural background. Moreover, these low-lying areas are also receiving industrial, agricultural and urban waste from other parts of the country via local stream network and Indus river system, which may further flush out into Arabian sea or re-emitted through volatilization (Eqani et al. 2016).

\section{Air-Water exchange gradients of OCPs and PCBs}

In general, considering zone wise results of air-water exchange of OCPs, there were net deposition of DDT isomers ( $\left.p, p^{\prime}-D D T\right)$ and its metabolites at all studied zones, which might be due to its current illegal use in the region for crop protection and malarial control, and resulted into elevated levels of atmospheric OCPs and finally deposition into surrounding water bodies. However, few exceptions of net volatilization of DDTs metabolites into FMZ highlighted its re-emission from POPs repositories (via historical cold trapping) at various colder sites as also described by (Chen et al. 2008, Wania \&Westgate 2008) and entered into Indus water via melt down of glaciers and ice masses located in the FMZ and WMZ and continually volatilizing into ambient air in these pristine areas (Nasir et al. 2014). This study implies that the trend of air-water exchange of PCBs is volatilization from water to the air at most of the sites. Considering zone wise results of air-water exchange of PCBs, there were net volatilization of all the different PCBs at the FMZ, WMZ and ARZ, which highlighted the re-emission of PCBs from POPs repositories (via historical cold trapping) at various colder sites (Chen et al. 2008, Daly \&Wania 2005, Wania \&Westgate 2008) and entered into Indus water via melt down of glaciers and ice masses located in the FMZ and WMZ and continually volatilizing into ambient air in these pristine areas. In case of ARZ, 
the industrial waste/effluent into Indus River are also significantly adding up levels of PCBs, which continually volatilizing into ambient air via temperature rise in summer season (Eqani et al. 2012b). However, net deposition at LLZ might be due to huge amount of industrial activities in the region and due to current usage.

Toxicity assessment due to OCPs and PCBs

Toxicity assessment showed that PCB and DDTs metabolites are well below the Criterion Continuous Concentration (CMC) and Criterion Continuous Concentration (CCC) values for all the studied zones (Table. S4). Similarly, none of the other OCPs isomers exceeded the established Maximum admissible concentrations (MAC) and Annual Average concentrations (AA) values by the European Council (Table. S4), suggesting low ecological risk associated with the levels of OCPS/PCBs into the Indus River. However, it is well known that these chemicals have potential to bioaccumulate due to their lipophilic characteristics $\left(\log \mathrm{K}_{\mathrm{ow}}\right)$ and even at very low levels into the fresh water system, contributed significantly towards the total body burdens into the aquatic organisms (fish) and subsequent food chain and finally associated humans.

We calculated the chemical daily intake (CDI) estimates for the assessment of intake of chemicals via various routes (i.e., ingestion and dermal) contact into the associated human body. Using values of dissolved OCPs and PCBs in the Indus River, CDI (pg/person/day) for oral and dermal exposure for p,p'DDD ranged from $1.26-12.65$ and $0.003-0.03$, for p,p'-DDE $6.51-97.49$ and $0.01-0.23$, for p,p'-DDT $3.51-23.97$ and $0.008-5.82$, for $\mathrm{Y}-\mathrm{HCH} /$ lindane 1.28 and 0.003 , for $\Sigma$ Chlordane $0.99-3.15$ and $0.002-$ 0.007 and for $\Sigma P C B s 28.89-233.33$ and $0.07-0.57$ (Table. 3). The Hazard Quotient (HQ) for OCPs and PCBs exposure were taken by dividing the CDIs value with reference doses $\left(\mathrm{R} f_{o} \mathrm{Ds}\right)$ and for cancer risk (CR) multiplying CDIs value by SFs (USEPA, 2011). In health risk assessment for human when HQ or HI > 1 , is considered as benchmark for sub-chronic and chronic (non-carcinogenic) human health risk of OCPs/PCBs (USEPA, 2005). HI values (even less than unity) could be useful to estimate the water matrix contribution to develop non-cancer health risks, which along with the other sources (i.e. dust and diet) adding cumulative risk of OCPs/PCBs into the associated exposed population (USEPA, 2001). Furthermore, exposure to low-level of OCPs/PCBs (oral or dermal) by the drinking water may also result into carcinogenic effects into human which is an indicator for potential cancer risk (CR). If $\mathrm{CR}$ is greater than $10^{-6}$ then CR exists in the exposed population due to OCPs/PCBs-contaminated water intake (USEPA, 2005). The potential carcinogenic risk (CR) values for oral and dermal from FMZ ranged from $1.66 \mathrm{x}$ $10^{-10}-5.96 \times 10^{-12}$ and $2.64 \times 10^{-13}-6.8 \times 10^{-14}$, WMZ $1.73 \times 10^{-11}-4.95 \times 10^{-12}$ and $1.07 \times 10^{-}$ $14-7.77 \times 10^{-14}$, ARZ $4.95 \times 10^{-12}-4.34 \times 10^{-1}$ and $1.15 \times 10^{-12}-5.80 \times 10^{-14}$ and for LLZ $1.63 \times 10^{-}$ ${ }^{10}-5.93 \times 10^{-12}$ and $1.22 \times 10^{-13}-2.56 \times 10^{-14}$ for all studied OCPs. The carcinogenic risk (CR) for ¿PCBs $1.059 \times 10^{-9}-9.13 \times 10^{-10}$ from oral exposure and $2.227 \times 10^{-12}-4.2 \times 10^{-13}$ for dermal exposure. Although, it has been observed that their no/low known carcinogenic risk from both OCPs and PCBs through oral and dermal exposure of water from the different studied zone in Indus River (Fig. S5 \& S6). Nevertheless, according to recent report describing the effects of toxic stimuli combinations on 
determination of safe exposure limits has been published and concluded that there is no reason to believe today that any of the Exposure Limits on potentially toxic stimuli that have been set by any of the regulatory agencies are fully protective against serious adverse health effects (Kostoff 2018). Moreover, this study highlighted the contribution of water matrix via non-carcinogenic and carcinogenic risk, which in addition to dust, soil and biota (diet), may pose several health problems to associated human population.

\section{Conclusion}

This is the first study reported authenticated data of dissolved OCPs and PCBs measured through the passive water sampling by using polyethylene sheets (LPDE) throughout the Indus River, Pakistan. In general, the Indus River water is being moderately contaminated with OCPs and PCBs when compared with the other water bodies throughout the world. Our zone- wise results of air-water exchange of OCPS and PCBs reflected the cycling of POPs (volatilization and deposition) along the Indus River, Pakistan, which may be due to rapid land use, abruptive climate change and regional atmospheric influences. Our results also highlighted the LRAT of POPs into northern colder areas Pakistan and highlighted the reemission of POPs from their repositories (via historical cold trapping) at various colder sites. These POPs likely entered the Indus via melting of glaciers and ice masses and which also continually volatilizing the POPs into ambient air of these pristine areas. Nevertheless, local sources also contributed towards the recent emission of these toxic chemicals (especially DDTs), which are being used for agricultural and industrial purposes and transported/deposited into the entire geographic zones along Indus river ecosystem by wet/dry deposition process.

\section{Declarations}

\section{Ethical Approval}

Not applicable

\section{Consent to Participate}

Not applicable

Consent to Publish

Not applicable

Competing of Interest

None

\section{Acknowledgement}


The authors acknowledge the financial support of Higher Education Commission (HEC) of Pakistan for funding this study under HEC Indigenous PhD 5000 Fellowship Program and International research support initiative program (IRSIP) of HEC, Pakistan.

\section{Author contribution}

Muhammad Sohail, Syed Ali Musstjab Akber Shah Eqani, Habib Bokhari, and Muhammad Zaffar Hashmi develop idea, wrote and supervise the research, Nadeem Ali, Ambreen Alamdar, Joel E Podgorski, Dave Adelman, and Rainer Lohmann wrote, provided technical support and improved the manuscript.

\section{Funding}

The authors acknowledge the financial support of Higher Education Commission (HEC) of Pakistan for funding this study under HEC Indigenous PhD 5000 Fellowship Program and International research support initiative program (IRSIP) of HEC, Pakistan.

\section{Availability of data and materials}

The study was conducted in Pakistan and data was analyzed properly.

\section{References}

1. Abbasi G, Buser AM, Soehl A, Murray MW, Diamond ML (2015): Stocks and flows of PBDEs in products from use to waste in the US and Canada from 1970 to 2020 . Environmental science \& technology 49, 1521-1528

2. Ahad K, Mohammad A, Mehboob F, Sattar A, Ahmad I (2006): Pesticide residues in rawal lake, Islamabad, Pakistan. Bulletin of environmental contamination and toxicology 76, 463-470

3. Ahad K, Mohammad A, Khan H, Ahmad I, Hayat Y (2010): Monitoring results for organochlorine pesticides in soil and water from selected obsolete pesticide stores in Pakistan. Environmental monitoring and assessment 166, 191-199

4. Alamdar A, Eqani SAMAS, Ali SW, Sohail M, Bhowmik AK, Cincinelli A, Subhani M, Ghaffar B, Ullah R, Huang Q (2016): Human Arsenic exposure via dust across the different ecological zones of Pakistan. Ecotoxicology and environmental safety $126,219-227$

5. Ali N, Eqani SAMAS, Malik RN, Neels H, Covaci A (2013): Organohalogenated contaminants (OHCs) in human serum of mothers and children from Pakistan with urban and rural residential settings. Science of The Total Environment 461, 655-662

6. Ali N, Mehdi T, Malik RN, Eqani SA, Kamal A, Dirtu AC, Neels H, Covaci A (2014): Levels and profile of several classes of organic contaminants in matched indoor dust and serum samples from occupational settings of Pakistan. Environmental Pollution 193, 269-276

7. Ali U, Sweetman AJ, Riaz R, Jones KC, Malik RN (2017): Organohalogenated contaminants (OHCs) in high-altitude environments: A review and implication for a black carbon relationship. Critical Reviews 
in Environmental Science and Technology 47, 1143-1190

8. Anderson DJ, Bloem TB, Blankenbaker RK, Stanko TA (1999): Concentrations of polychlorinated biphenyls in the water column of the Laurentian Great Lakes: Spring 1993. Journal of Great Lakes Research 25, 160-170

9. Baqar M, Sadef Y, Ahmad SR, Mahmood A, Li J, Zhang G (2018): Organochlorine pesticides across the tributaries of River Ravi, Pakistan: Human health risk assessment through dermal exposure, ecological risks, source fingerprints and spatio-temporal distribution. Science of The Total Environment 618, 291-305

10. Bertazzi PA, Bernucci I, Brambilla G, Consonni D, Pesatori AC (1998): The Seveso studies on early and long-term effects of dioxin exposure: a review. Environmental Health Perspectives 106, 625

11. Blais JM, Schindler DW, Muir DC, Kimpe LE, Donald DB, Rosenberg B (1998): Accumulation of persistent organochlorine compounds in mountains of western Canada. Nature 395, 585-588

12. Blais JM, Schindler DW, Muir DC, Sharp M, Donald D, Lafreniere M, Braekevelt E, Strachan WM (2001): Melting glaciers: a major source of persistent organochlorines to subalpine Bow Lake in Banff National Park, Canada. AMBIO: A Journal of the Human Environment 30, 410-415

13. Blanchard P, Audette CV, Hulting ML, Basu I, Brice KA, Backus SM, Dryfhout-Clark H, Froude F, Hites RA, Neilson M (2008): Atmospheric deposition of toxic substances to the Great Lakes: IADN results through 2005. US Environmental Protection Agency and Environment Canada, Canada Catalogue No. En56-156 E 2005

14. Chen D, Liu W, Liu X, Westgate JN, Wania F (2008): Cold-trapping of persistent organic pollutants in the mountain soils of Western Sichuan, China. Environmental science \& technology 42, 9086-9091

15. Cincinelli A, Dickhut R (2011): LEVELS AND TRENDS OF ORGANOCHLORINE PESTICIDES (OCPS) IN ANTARCTICA. Environmental Research Journal 5

16. Daly GL, Wania F (2005): Organic contaminants in mountains. Environmental science \& technology 39, 385-398

17. Davidson DA, Wilkinson AC, Blais JM, Kimpe LE, McDonald KM, Schindler DW (2003): Orographic cold-trapping of persistent organic pollutants by vegetation in mountains of western Canada. Environmental science \& technology 37, 209-215

18. Dirtu AC, Covaci A (2010): Estimation of daily intake of organohalogenated contaminants from food consumption and indoor dust ingestion in Romania. Environmental science \& technology 44, 62976304

19. Dougherty CP, Holtz SH, Reinert JC, Panyacosit L, Axelrad DA, Woodruff TJ (2000): Dietary exposures to food contaminants across the United States. Environmental Research 84, 170-185

20. Eqani SA-M-A-S, Malik RN, Mohammad A (2011): The level and distribution of selected organochlorine pesticides in sediments from River Chenab, Pakistan. Environmental geochemistry and health 33, 33-47

21. Eqani SA-M-A-S, Malik RN, Alamdar A, Faheem H (2012a): Status of organochlorine contaminants in the different environmental compartments of Pakistan: a review on occurrence and levels. Bulletin of 
environmental contamination and toxicology 88, 303-310

22. Eqani SA-M-A-S, Malik RN, Katsoyiannis A, Zhang G, Chakraborty P, Mohammad A, Jones KC (2012b): Distribution and risk assessment of organochlorine contaminants in surface water from River Chenab, Pakistan. Journal of Environmental Monitoring 14, 1645-1654

23. Eqani SA-M-A-S, Malik RN, Cincinelli A, Zhang G, Mohammad A, Qadir A, Rashid A, Bokhari H, Jones KC, Katsoyiannis A (2013): Uptake of organochlorine pesticides (OCPs) and polychlorinated biphenyls (PCBs) by river water fish: the case of River Chenab. Science of the Total Environment 450, 83-91

24. Eqani SAMAS, Kanwal A, Bhowmik AK, Sohail M, Ullah R, Ali SM, Alamdar A, Ali N, Fasola M, Shen H (2016): Spatial distribution of dust-bound trace elements in Pakistan and their implications for human exposure. Environmental Pollution 213, 213-222

25. Gao J, Zhou H, Pan G, Wang J, Chen B (2013): Factors influencing the persistence of organochlorine pesticides in surface soil from the region around the Hongze Lake, China. Science of the Total Environment 443, 7-13

26. Gioia R, Eckhardt S, Breivik K, Jaward FM, Prieto A, Nizzetto L, Jones KC (2011): Evidence for major emissions of PCBs in the West African region. Environmental science \& technology 45, 1349-1355

27. Gulland $F$ (1995): The impact of infectious diseases on wild animal populations: a review. Ecology of infectious diseases in natural populations. Cambridge University Press, Cambridge, 20-51

28. Harner T, Bartkow M, Holoubek I, Klanova J, Wania F, Gioia R, Moeckel C, Sweetman AJ, Jones KC (2006): Passive air sampling for persistent organic pollutants: Introductory remarks to the special issue. Environmental Pollution 144, 361-364

29. Hoff R, Strachan W, Sweet C, Chan C, Shackleton M, Bidleman T, Brice K, Burniston D, Cussion S, Gatz D (1996): Atmospheric deposition of toxic chemicals to the Great Lakes: a review of data through 1994. Atmospheric Environment 30, 3505-3527

30. Iqbal M, Breivik K, Syed JH, Malik RN, Li J, Zhang G, Jones KC (2015): Emerging issue of e-waste in Pakistan: A review of status, research needs and data gaps. Environmental pollution 207, 308-318

31. Iqbal M, Syed JH, Breivik K, Chaudhry MJI, Li J, Zhang G, Malik RN (2017): E-waste driven pollution in Pakistan: The first evidence of environmental and human exposure to flame retardants (FRs) in Karachi City. Environmental science \& technology 51, 13895-13905

32. Islam R, Kumar S, Karmoker J, Kamruzzaman M, Rahman MA, Biswas N, Tran TKA, Rahman MM (2018): Bioaccumulation and adverse effects of persistent organic pollutants (POPs) on ecosystems and human exposure: A review study on Bangladesh perspectives. Environmental Technology \& Innovation 12, 115-131

33. Jiang Y-F, Wang X-T, Jia Y, Wang F, Wu M-H, Sheng G-Y, Fu J-M (2009): Occurrence, distribution and possible sources of organochlorine pesticides in agricultural soil of Shanghai, China. Journal of Hazardous Materials 170, 989-997

34. Johnson-Restrepo B, Kannan K, Rapaport DP, Rodan BD (2005): Polybrominated diphenyl ethers and polychlorinated biphenyls in human adipose tissue from New York. Environmental science \& 
technology 39, 5177-5182

35. Kalyoncu L, Agca I, Aktumsek A (2009): Some organochlorine pesticide residues in fish species in Konya, Turkey. Chemosphere 74, 885-889

36. Khairy M, Muir D, Teixeira C, Lohmann R (2014): Spatial trends, sources, and air-water exchange of organochlorine pesticides in the Great Lakes basin using low density polyethylene passive samplers. Environmental science \& technology 48, 9315-9324

37. Khairy MA, Lohmann R (2012): Field validation of polyethylene passive air samplers for parent and alkylated PAHs in Alexandria, Egypt. Environmental science \& technology 46, 3990-3998

38. Khairy MA, Lohmann R (2013): Feasibility of using low density polyethylene sheets to detect atmospheric organochlorine pesticides in Alexandria, Egypt. Environmental pollution 181, 151-158

39. Khan MU, Besis A, Li J, Zhang G, Malik RN (2017): New insight into the distribution pattern, levels, and risk diagnosis of FRs in indoor and outdoor air at low-and high-altitude zones of Pakistan: Implications for sources and exposure. Chemosphere 184, 1372-1387

40. Kortenkamp A (2008): Low dose mixture effects of endocrine disrupters: implications for risk assessment and epidemiology. International journal of andrology 31, 233-240

41. Kostoff RN (2018): Effects of Toxic Stimuli Combinations on Determination of Exposure Limits.

42. Lee D-H, Steffes MW, Sjödin A, Jones RS, Needham LL, Jacobs Jr DR (2010): Low dose of some persistent organic pollutants predicts type 2 diabetes: a nested case-control study. Environmental health perspectives 118, 1235

43. Levy W, Henkelmann B, Pfister G, Bernhöft S, Kirchner M, Jakobi G, Bassan R, Kräuchi N, Schramm KW (2009): Long-term air monitoring of organochlorine pesticides using Semi Permeable Membrane Devices (SPMDs) in the Alps. Environmental pollution 157, 3272-3279

44. Lohmann R, Muir D (2010): Global aquatic passive sampling (AQUA-GAPS): using passive samplers to monitor POPs in the waters of the world. ACS Publications

45. Luo X, Mai B, Yang Q, Fu J, Sheng G, Wang Z (2004): Polycyclic aromatic hydrocarbons (PAHs) and organochlorine pesticides in water columns from the Pearl River and the Macao harbor in the Pearl River Delta in South China. Marine Pollution Bulletin 48, 1102-1115

46. Maes J, Belpaire C, Goemans G (2008): Spatial variations and temporal trends between 1994 and 2005 in polychlorinated biphenyls, organochlorine pesticides and heavy metals in European eel (Anguilla anguilla L.) in Flanders, Belgium. Environmental pollution 153, 223-237

47. Malik RN, Rauf S, Mohammad A, Eqani S-A-M-AS, Ahad K (2011): Organochlorine residual concentrations in cattle egret from the Punjab Province, Pakistan. Environmental monitoring and assessment 173, 325-341

48. Meire RO, Khairy M, Targino AC, Galvão PMA, Torres JPM, Malm O, Lohmann R (2016): Use of passive samplers to detect organochlorine pesticides in air and water at wetland mountain region sites (S-SE Brazil). Chemosphere 144, 2175-2182 
49. Nasir J, Wang X, Xu B, Wang C, Joswiak DR, Rehman S, Lodhi A, Shafiq S, Jilani R (2014): Selected organochlorine pesticides and polychlorinated biphenyls in urban atmosphere of Pakistan: concentration, spatial variation and sources. Environmental science \& technology 48, 2610-2618

50. Nawab J, Wang X, Khan S, Tang Y-T, Rahman Z, Ali A, Dotel J, Li G (2020): New insights into the bioaccumulation of persistent organic pollutants in remote alpine lakes located in Himalayas, Pakistan. Environmental Pollution, 114952

51. Olsson A, Valters K, Burreau S (2000): Concentrations of organochlorine substances in relation to fish size and trophic position: a study on perch (Perca fluviatilis L.). Environmental science \& technology 34, 4878-4886

52. Qiu X, Zhu T, Yao B, Hu J, Hu S (2005): Contribution of dicofol to the current DDT pollution in China. Environmental Science \& Technology 39, 4385-4390

53. Sacks VP, Lohmann R (2011): Development and use of polyethylene passive samplers to detect triclosans and alkylphenols in an urban estuary. Environmental science \& technology 45, 2270-2277

54. Sanpera C, Ruiz X, Jover L, Llorente G, Jabeen R, Muhammad A, Boncompagni E, Fasola M (2003): Persistent organic pollutants in little egret eggs from selected wetlands in Pakistan. Archives of environmental contamination and toxicology 44, 0360-0368

55. Schäfer RB, Paschke A, Vrana B, Mueller R, Liess M (2008): Performance of the Chemcatcher® passive sampler when used to monitor 10 polar and semi-polar pesticides in 16 Central European streams, and comparison with two other sampling methods. Water research 42, 2707-2717

56. Schäfer RB, Hearn L, Kefford BJ, Mueller JF, Nugegoda D (2010): Using silicone passive samplers to detect polycyclic aromatic hydrocarbons from wildfires in streams and potential acute effects for invertebrate communities. Water research 44, 4590-4600

57. Schreiber R, Harguinteguy CA, Manetti MD (2013): Dynamics of organochlorine contaminants in surface water and in Myriophyllum aquaticum plants of the River Xanaes in Central Argentina during the annual dry season. Archives of environmental contamination and toxicology 65, 466-473

58. Shaw M, Mueller JF (2009): Time integrative passive sampling: how well do chemcatchers integrate fluctuating pollutant concentrations? Environmental science \& technology 43, 1443-1448

59. Sohail M, Eqani SAMAS, Podgorski J, Bhowmik AK, Mahmood A, Ali N, Sabo-Attwood T, Bokhari H, Shen H (2018): Persistent organic pollutant emission via dust deposition throughout Pakistan: Spatial patterns, regional cycling and their implication for human health risks. Science of The Total Environment 618, 829-837

60. Sreenivasa Rao A, Ramamohana Rao P (2000): Kolleru lake water pollution by pesticides. Indian Journal of Environmental Health 42, 169-175

61. Sweetman AJ, Jones KC (2000): Declining PCB concentrations in the UK atmosphere: evidence and possible causes. Environmental science \& technology 34, 863-869

62. Tang X, Shen C, Shi D, Cheema SA, Khan MI, Zhang C, Chen Y (2010): Heavy metal and persistent organic compound contamination in soil from Wenling: an emerging e-waste recycling city in Taizhou area, China. Journal of Hazardous Materials 173, 653-660 
63. Tang Z, Yang Z, Shen Z, Niu J, Cai Y (2008): Residues of organochlorine pesticides in water and suspended particulate matter from the Yangtze River catchment of Wuhan, China. Environmental monitoring and assessment 137, 427-439

64. Taylor KW, Novak RF, Anderson HA, Birnbaum LS, Blystone C, DeVito M, Jacobs D, Köhrle J, Lee D-H, Rylander $L$ (2013): Evaluation of the association between persistent organic pollutants (POPs) and diabetes in epidemiological studies: a national toxicology program workshop review. Environmental health perspectives 121,774

65. Tolosa I, Mesa-Albernas M, Alonso-Hernandez C (2010): Organochlorine contamination (PCBs, DDTs, HCB, HCHs) in sediments from Cienfuegos bay, Cuba. Marine pollution bulletin 60, 1619-1624

66. Wania F, Haugen J-E (1999): Long term measurements of wet deposition and precipitation scavenging of hexachlorocyclohexanes in Southern Norway. Environmental Pollution 105, 381-386

67. Wania F, Westgate JN (2008): On the mechanism of mountain cold-trapping of organic chemicals. Environmental science \& technology 42, 9092-9098

68. Weber J, Halsall CJ, Muir D, Teixeira C, Small J, Solomon K, Hermanson M, Hung H, Bidleman T (2010): Endosulfan, a global pesticide: a review of its fate in the environment and occurrence in the Arctic. Science of the Total Environment 408, 2966-2984

69. Whitehead TP, Smith SC, Park J-S, Petreas MX, Rappaport SM, Metayer C (2015): Concentrations of persistent organic pollutants in California women's serum and residential dust. Environmental research 136, 57-66

70. Wong CS, Wu S, Duzgoren-Aydin NS, Aydin A, Wong MH (2007): Trace metal contamination of sediments in an e-waste processing village in China. Environmental Pollution 145, 434-442

71. Zhang H, Luo Y, Zhao Q, Wong M, Zhang G (2006): Residues of organochlorine pesticides in Hong Kong soils. Chemosphere 63, 633-641

72. Zhang L, Lohmann R (2010): Cycling of PCBs and HCB in the surface ocean-lower atmosphere of the open Pacific. Environmental science \& technology 44, 3832-3838

73. Zhang Z, Hong H, Zhou J, Huang J, Yu G (2003): Fate and assessment of persistent organic pollutants in water and sediment from Minjiang River Estuary, Southeast China. Chemosphere 52, $1423-1430$

74. Zhang Z, Huang J, Yu G, Hong H (2004): Occurrence of PAHs, PCBs and organochlorine pesticides in the Tonghui River of Beijing, China. Environmental Pollution 130, 249-261

75. Zhao G, Xu Y, Han G, Ling B (2006): Biotransfer of persistent organic pollutants from a large site in China used for the disassembly of electronic and electrical waste. Environmental geochemistry and health 28, 341-351

76. Zhao S, Breivik K, Liu G, Zheng M, Jones KC, Sweetman AJ (2017): Long-Term Temporal Trends of Polychlorinated Biphenyls and Their Controlling Sources in China. Environmental Science \& Technology 51, 2838-2845

77. Zhao Z, Zhang L, Wu J, Fan C, Shang J (2010): Assessment of the potential mutagenicity of organochlorine pesticides (OCPs) in contaminated sediments from Taihu Lake, China. Mutation 
Research/Genetic Toxicology and Environmental Mutagenesis 696, 62-68

78. Zhou J, Maskaoui K, Qiu Y, Hong H, Wang Z (2001): Polychlorinated biphenyl congeners and organochlorine insecticides in the water column and sediments of Daya Bay, China. Environmental Pollution 113, 373-384

\section{Figures}

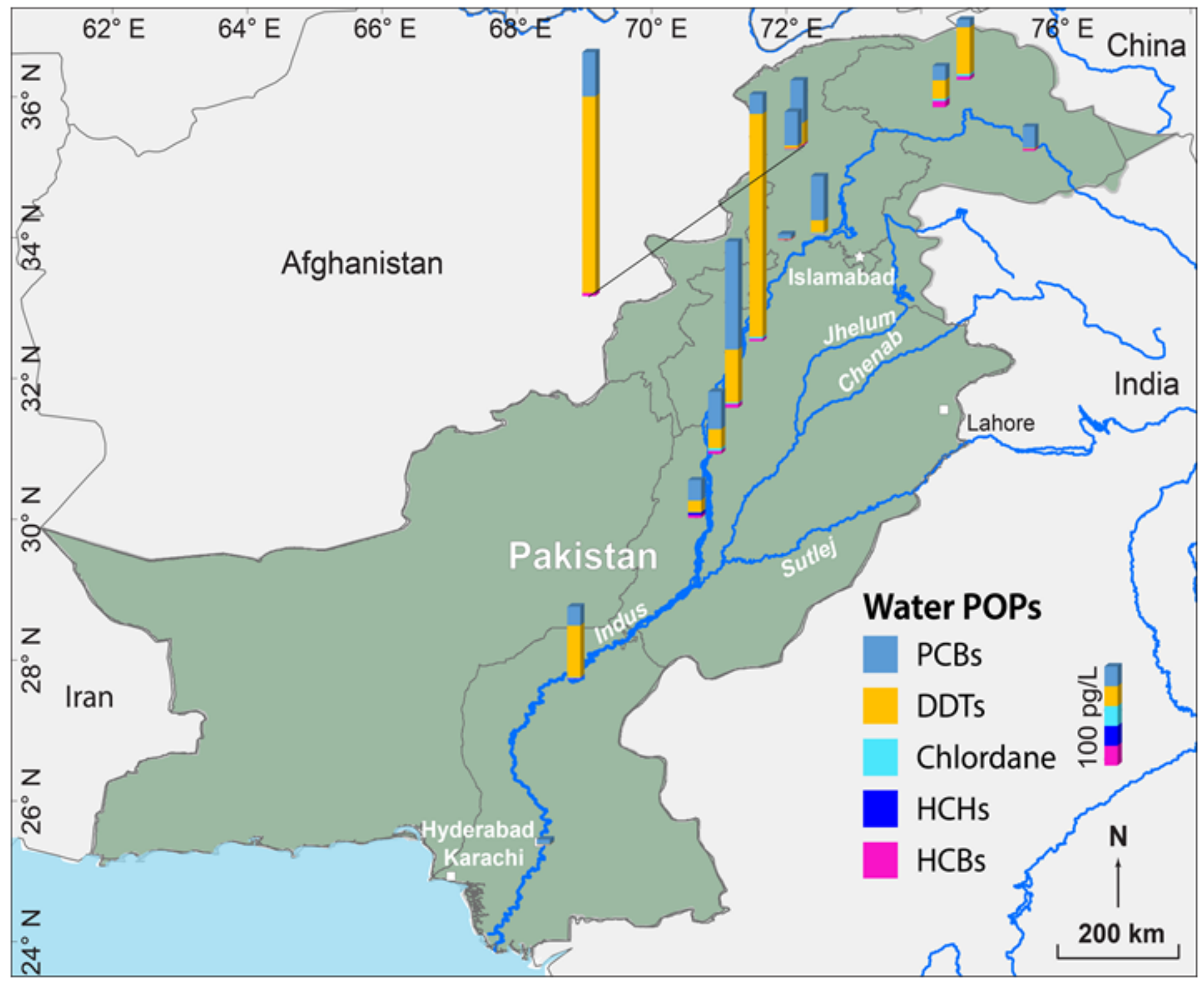

\section{Figure 1}

Freely dissolved OCPs and PCBs, Chlordane, $\mathrm{HCHs}$ and HCBs along the Indus River, Pakistan. Note: The designations employed and the presentation of the material on this map do not imply the expression of any opinion whatsoever on the part of Research Square concerning the legal status of any country, territory, city or area or of its authorities, or concerning the delimitation of its frontiers or boundaries. This map has been provided by the authors. 

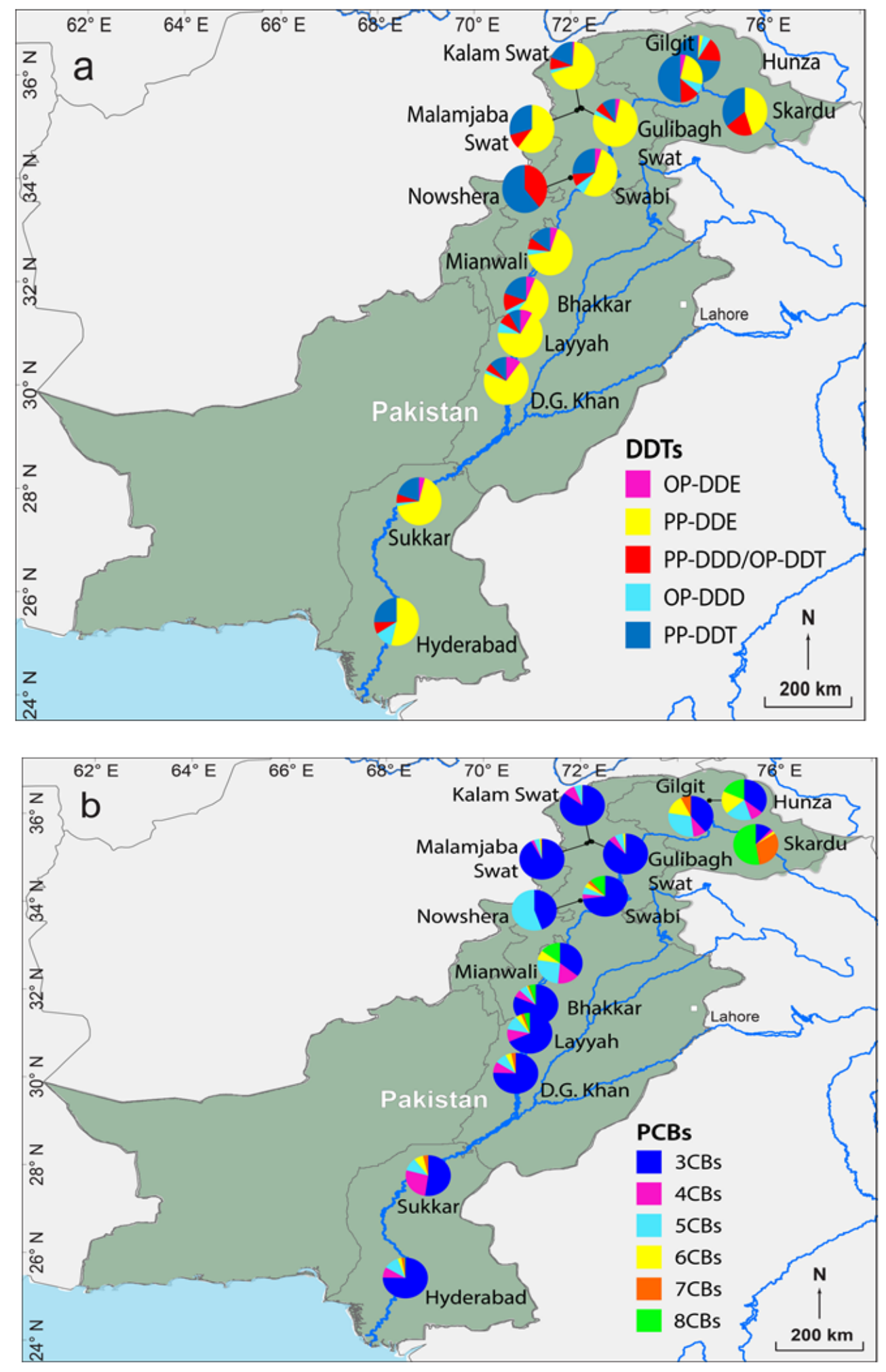

\section{Figure 2}

Compositional profile of freely dissolved (a) DDTs and (b) PCBs along the Indus River, Pakistan. Note: The designations employed and the presentation of the material on this map do not imply the expression of any opinion whatsoever on the part of Research Square concerning the legal status of any country, territory, city or area or of its authorities, or concerning the delimitation of its frontiers or boundaries. This map has been provided by the authors. 

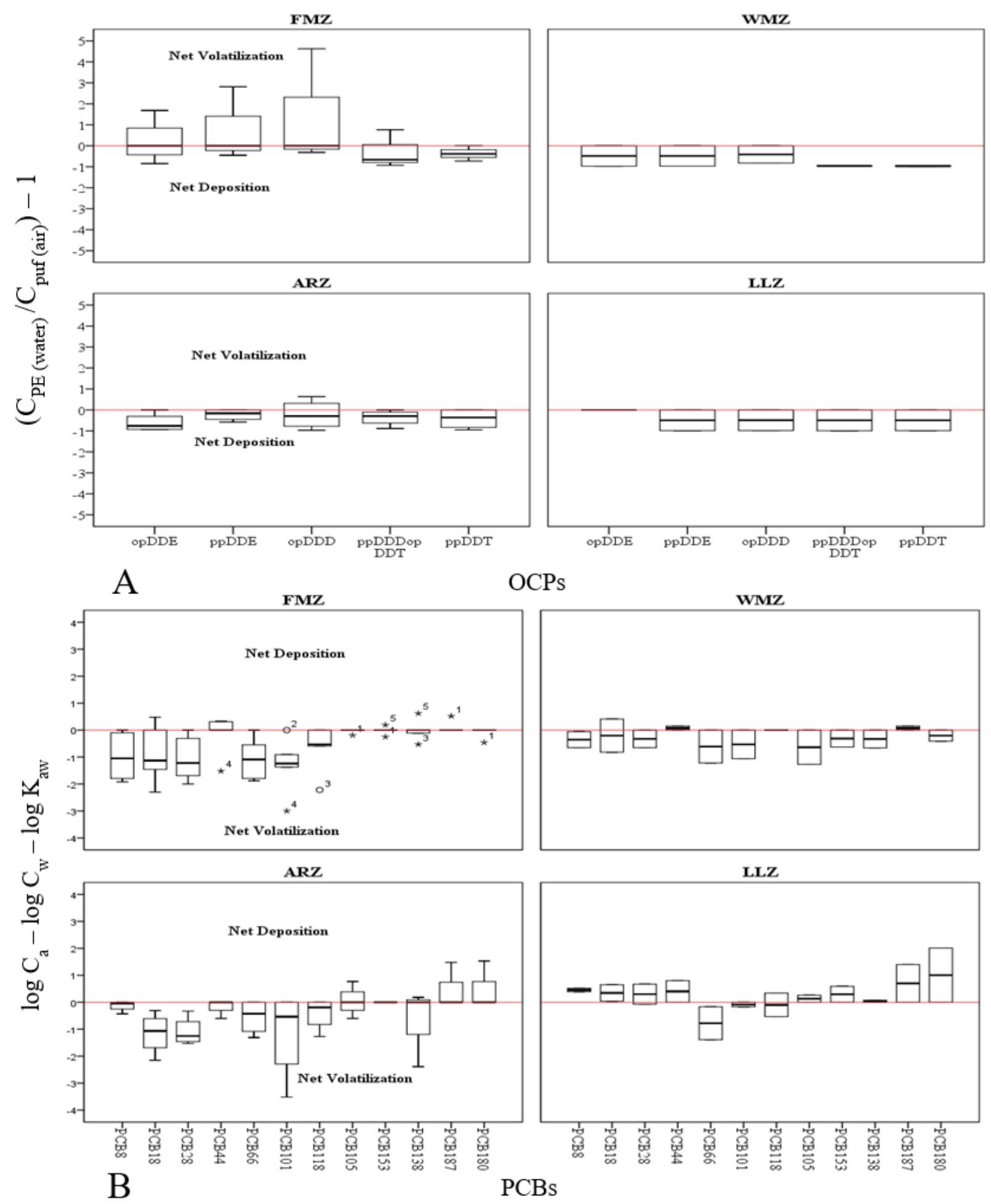

\section{Figure 3}

Air-Water exchange of DDTs (a) and PCBs (b) along Indus River Flood-plain, Pakistan.

\section{Supplementary Files}

This is a list of supplementary files associated with this preprint. Click to download. 
- Revised2.SIEQSOHIndusPOPSrl.doc 